\title{
On the spectral properties of a class of high-order differential operators with operator coefficients
}

\begin{abstract}
In this paper, we study one class of high-order differential operators. The main feature of these operators is their nonsemi-boundedness. The dependence of operator coefficients on variables creates additional difficulties in the study. In the course of the study, the conditions for the existence of a solution and separability were first found. Also studied are the questions of the smoothness of solutions and on the spectrum of boundary value problems for unbounded differential equations with variable operator coefficients
\end{abstract}

Keywords: a differential operator, nonsemi-boundedness, an operator coefficient, a spectrum.

\section{Introduction. Formulation of the problem. Statement of the main results}

Boundary value problems for differential equations with operator coefficients are studied in the papers of B.M. Levitan [1], M. Otelbaev [2], B.A. Suvorchenkov [3], V.I. Gorbachuk, M.L. Gorbachuk [4], I.M. Gehtman [5], V.A. Mikhlets [6], P.A. Mishnevsky [7], K.N. Ospanov [8] and others. Note that in all these papers are studied differential operators with operator coefficients of even, first, and third order, i.e. the so-called semi-bounded differential operators and operators with a coercive estimate

$$
\sum_{|\alpha| \leq 2 m}\left|a_{\alpha}(x) s^{\alpha}\right| \leq c|p(x, s)|
$$

where $p(x, s)=\sum_{|\alpha| \leq 2 m} a_{\alpha}(x) s^{\alpha}, x \in R^{n}$, and $s \in \mathbb{R}^{n}$ and $\rho$ is a polynomial differential operator $L u=\sum_{|\alpha| \leq 2 m} D_{x}^{\alpha} u, \alpha=\left(\alpha_{1}, \alpha_{2}, \ldots, \alpha_{n}\right),|\alpha|=\sum_{i=0}^{n} \alpha_{i}$,

$$
D_{x}^{\alpha}=\left(\left(\frac{1}{i} \cdot \frac{\partial u}{\partial x_{1}}\right)^{\alpha_{1}}, \ldots,\left(\frac{1}{i} \cdot \frac{\partial u}{\partial x_{n}}\right)^{\alpha_{n}}\right), i^{2}=-1 .
$$

However, in applications often appear differential equations with operator coefficients that do not satisfy the above conditions. For example, in particular, unbounded differential equations with operator coefficients that arise in the theory of differential equations of hyperbolic and mixed types. This case was first studied systematically in the paper of M.B. Muratbekov [9]. In this paper of the author, the case was studied when the operator potential is independent of variables. It is known that a completely different situation arises in the study of differential equations with variable operator coefficients, i.e. when operator coefficients depend on variables. In this case, the main difficulty lies in the fact that the spectrum of the operator coefficient depends on variables, and therefore, the expansion of an arbitrary function in a series of eigenfunctions becomes impossible. Therefore, the well-known methods used in the works of the above authors turn out to be little adapted when studying the questions of separability, smoothness of solutions, and the spectrum of boundary value problems for unbounded differential equations with variable operator coefficients. this paper is devoted to these pressing issues.

We believe that our results are of theoretical interest and can find application in the spectral theory of differential operators, in quantum mechanics and gas dynamics. 
Let $H$ is the Hilbert abstract separable space. Denote by $H_{1}=L_{2}(R, H)$ the Hilbert space obtained by the completion of the set of compactly supported infinitely smooth vector functions $C_{o}^{\infty}(R, H)$ defined on $R=(-\infty,+\infty)$ with value in $H$ by norm

$$
\|u(y)\|_{H_{1}}=\left(\int_{-\infty}^{+\infty}\|u(y)\|_{H}^{2} d y\right)^{\frac{1}{2}}
$$

which corresponds to the scalar product

$$
<u(y), v(y)>_{H_{1}}=\int_{-\infty}^{+\infty}<u(y), v(y)>_{H} d y .
$$

In a given space the following differential equation is considered

$$
L u \equiv-u^{\prime \prime}(y)+k(y) A(y) u+i a(y) A^{\alpha}(y)+c(y) u=f \in H_{1},
$$

Here $A$ is a positive definite self-adjoint variable-dependent operator with completely continuous inverse operator, $y \in H, \alpha \in\left[\frac{1}{2}, 1\right], k(y)$ is a piecewise continuous and bounded function in $R, k(0)=0$ and $y k(y)>0$ at $y \neq 0$.

By $L$ we denote the closed operator corresponding to equation (1) in $H_{1}$. By the solution of equation (1) we mean the function $u \in H_{1}$ if there exists a sequence $\left\{u_{n}\right\}_{n=1}^{\infty,} \in C_{o}^{\infty}(R, H)$ such that

$$
\left\|u_{n}-u\right\|_{H_{1}} \rightarrow 0,\left\|L u_{n}-f\right\|_{H_{1}} \rightarrow 0
$$

as

$$
n \rightarrow \infty .
$$

Hence it is easy to verify that finding a unique solution to equation (1) means proving the invertibility of the operator $L$ for all $f \in H_{1}$.

Further statements of the results are given in the language of operators and we will use the results of $[9]$.

Theorem 1. Let the following conditions are fulfilled:

a) $|a(y)| \geq \delta_{0}>0$ is a continuous functions in $R$;

b) $\sup _{|y-t| \leq 1} \frac{a(y)}{a(t)} \leq c_{0}<\infty ; \sup _{|y-t| \leq 1} \frac{c(y)}{c(t)} \leq c_{1}<\infty$;

c) $\sup _{|y-t| \leq 1}\left\|\left(A^{\alpha}(y)-A^{\alpha}(t)\right) A^{-\alpha}\right\|_{H} \leq o(1), \alpha \in\left[\frac{1}{2}, 1\right]$;

d) $c(y) \leq c_{0} a^{2}(y)$, for all $y \in R, c_{0}$ is any constant. Then for the operator $L+\lambda E$ for sufficiently large $\lambda>0$ there exists a bounded inverse operator $(L+\lambda E)^{-1}$.

Theorem 2. Let conditions a)-c) are fulfilled. Then the estimate

$$
\left\|u^{\prime}(y)\right\|_{H_{1}}+\left\|i a(y) A^{\alpha}(y) u\right\|_{H_{1}}+\|c(y) u\|_{H_{1}} \leq c\|L u\|_{H_{1}},
$$

holds for all $u \in D(L)$, where $c>0$ is a constant independent of $u(y)$.

The following new results were obtained in the work:

- conditions are found on the coefficients of high-order differential operators with operator coefficients that provide the following properties: a) discreteness of the spectrum; b) spectrum continuity;

- a criterion is obtained for the discreteness of the spectrum of a high-order differential operator with operator coefficients;

- the relation $L^{-1} \in \sigma_{\rho}$ is proved, where $1<\rho<\infty$; 
- the class of high-order unbounded differential operators with operator coefficients whose resolvents are Hilbert-Schmidt operators is indicated.

In qualitative spectral analysis, a special place is given to the study of the existence of the spectrum. In the case of its existence, problems of discreteness and continuity of the spectrum are considered. Among the papers that are similar in theme and influenced these studies, we note the papers of B.M. Levitan, I.S. Sargsyan, A.G. Kostyuchenko, M. Otelbaev, T.Sh. Kalmenov, E.I. Moiseev, C.M. Ponomarev, M.B. Muratbekov, A.S. Berdyshev, K.N. Ospanov, K.Kh. Boymatov, W.N. Everitt, M. Girtz et al.

It is known that spectral analysis of differential operators studies the nature of the spectrum depending on the behavior of the coefficients, boundary conditions, and region geometry. As an example, the last case includes the following facts: in a bounded domain, the spectrum of an elliptic operator with smooth coefficients is always discrete, and in an unbounded domain, the spectrum of the same operator with a bounded coefficient is continuous.

The most significant issue of spectral theory in the study of the spectrum depending on the behavior of the coefficients is a sign of discreteness of the spectrum. The first significant result in this direction is the Molchanov criterion on compactness of the resolvent of the singular Sturm-Liouville equation. This result was then disseminated to an operator of Schrodinger type by M.Sh. Birman and B.S. Pavlov, V.G. Maz'ya, M. Otelbaev and R. Oinarov, M.G. Gasimov obtained a criterion for the compactness of their embedding in Lebesgue space studying the topologies of energy spaces of elliptic operators. Based on this approach, the result of A.M. Molchanov was extended to new classes of semi-bounded differential operators whose energy spaces are embedded in some Sobolev weighted spaces.

Now questions arise about the discreteness and continuity of the spectrum of unbounded differential operators. Here, a significant difficulty is the question of the smoothness of elements from the domain of definition of the operator in order to extract the necessary information regarding the structure of the spectrum. These questions have not been investigated for the operator below.

By $L$ we denote the closure in the norm $H_{1}=L_{2}(R, H)$ of the differential operator

$$
L u \equiv(-1)^{m} u^{(2 m)}(y)+k(y) A u+i a(y) A^{\alpha} u+c(y) u,
$$

defined on the set $C_{o}^{\infty}(R, H)$, where $m$ is a positive integer, $k(y)$ is a piecewise continuous and bounded function in $\mathbb{R}, A$ is a some non-negative self-adjoint operator in the Hilbert space $H$ with a completely continuous resolvent.

We shall assume that the coefficients $a(y), c(y)$ satisfy:

i) $|a(y)| \geq \delta_{0}>0, c(y) \geq \delta>0$ are continuous functions in $R$.

Theorem 3. Let the condition i) is fulfilled and $c(y)$ is a bounded function and let $\lambda=0$ be an eigenvalue of the operator $A$ with finite multiplicity. Then the continuous spectrum of $L$ is not empty.

Theorem 4. Let the condition i) is fulfilled. Then the discrete spectrum of $L$ is not empty if the equality

$$
\lim _{|y| \rightarrow \infty} \int_{y}^{y+\omega} c(t) d t=\infty .
$$

holds.

Theorem 5. Let the condition i) is fulfilled and let $A$ be a positive definite operator with completely continuous inverse. Then the spectrum of $L$ is discrete iff

$$
\lim _{|y| \rightarrow \infty} \int_{y}^{y+\omega} c(t) d t=\infty,
$$




$$
\lim _{|y| \rightarrow \infty} \int_{y}^{y+\omega}|a(t)| d t=\infty
$$

for all $\omega>0$. To prove the above theorems, we will use the following auxiliary statements and estimates.

2 On a one-dimensional high-order differential operator

Consider the differential operator

$$
l u=(-1)^{m} u^{(2 m)}(y)+c(y) u,
$$

initially defined on $C_{o}^{\infty}(R)$, with further closure of this operator in $L_{2}(R)$.

The following lemmas hold.

Lemma 1. Let the condition i) is fulfilled and let $c(y)$ be a limited function. Then the spectrum of the operator $l$ is purely continuous.

Proof. Denote by $l_{t}$ the operator defined by

$$
l_{t}=(-1)^{m} u^{(2 m)}+t u
$$

on $C_{o}^{\infty}(R)$, where $b=\sup _{t \in R} c(t)$. The operator $l_{t}$ admits closure in $L_{2}(R)$. Introduce new metrics in the domains $D(l), D\left(l_{t}\right)$ of the operators $l, l_{t}$, believing

$$
|u|_{l}=<l u, u>, u \in D(l) ;|u|_{l_{t}}=<l_{t} u, u>, u \in D\left(l_{b}\right) ;
$$

and close the domains $D(l), D\left(l_{t}\right)$ in these metrics.

The resulting new Hilbert space we denoted by $H_{l}, H_{l_{b}}$.

It is easy to see that $H_{l_{t}} \subset H_{l}$ и $|u|_{l_{t}} \geq|u|_{l}$. Therefore, we assume that $l_{t} \geq l$. Where $l$ and $l_{t}$ are positive operators.

From general compactness theorems it follows: if the spectrum of the operator $l$ is discrete, then the spectrum of the operator $l_{t}$ is also discrete; if the spectrum of the operator $l_{t}$ is continuous, then the spectrum of the operator $l$ is also continuous.

It is known from the spectral theory of differential operators that the spectrum of $l_{t}$ is continuous, then the spectrum of $l$ is also continuous. The lemma is proved.

Consider the operator

$$
l_{t} u=(-1)^{m} u^{(2 m)}+\left(t k(y)+i t^{\alpha} a(y)+c(y)\right) u,
$$

where $u \in D\left(l_{t}\right)$.

Lemma 2. Let the condition i) is fulfilled. Then the estimate

$$
c\left\|l_{t} u\right\|_{2}^{2} \geq \int_{-\infty}^{+\infty}\left[\left|u^{(m)}\right|^{2}+c\left((y)+|t|^{\alpha}|a(y)|\right)|u|^{2}\right] d y,
$$

holds for all $u \in D\left(l_{t}\right)$, where $c>0$ is a constant independent of $t, u$.

Proof. Here and below, without loss of generality, we assume $|a(y)| \geq 1, c(y) \geq 1$. Consider the scalar product

$$
<l_{t} u, u>=\int_{-\infty}^{+\infty}\left[\left|u^{(m)}\right|^{2}+\left(t k(y)+i t^{\alpha} a(y)+c(y)\right)|u|^{2}\right] d y
$$

where $u \in C_{o}^{\infty}(R)$. 
Further, since $a(y)$ does not change sign, we have:

$$
\left|<l_{t}, u>\right| \geq\left|t^{\alpha}\right| \int_{-\infty}^{+\infty}|a(y)||u|^{2} d y
$$

sing the Cauchy inequality with $\varepsilon>0$ from inequality (5) we obtain

$$
\frac{1}{2 \varepsilon}\left\|l_{t} u\right\|_{2}^{2}+\frac{\varepsilon}{2}\|u\|_{2}^{2} \geq \frac{1}{2}|t|^{\alpha} \int_{-\infty}^{+\infty}|a(y)|^{2}|u|^{2} d y+\frac{1}{2} \delta_{0}|t|^{\alpha}\|u\|_{2}^{2} .
$$

From this inequality, by virtue of the condition i) and $d<t<\infty$ we obtain the following estimate

$$
\frac{1}{2 \varepsilon}\left\|l_{t} u\right\|_{2}^{2} \geq \frac{1}{2}|t|^{\alpha} \int_{-\infty}^{+\infty}|a(y)|^{2}|u|^{2} d y
$$

Further, it follows from equality (4) that

$$
\begin{aligned}
&\left|<l_{t} u, u>\right|=\left|\int_{-\infty}^{+\infty}\left[\left|u^{(m)}\right|^{2}+\left(t k(y)+i t^{\alpha} a(y)+c(y)\right)|u|^{2}\right] d y\right| \geq \\
& \geq\left|\int_{-\infty}^{+\infty}\left[\left|u^{(m)}\right|^{2}+(t k(y)+c(y))|u|^{2}\right] d y\right| \geq \\
& \geq\left|\int_{-\infty}^{+\infty}\left[\left|u^{(m)}\right|^{2}+c(y)|u|^{2}\right] d y\right|-|t| \mid \int_{-\infty}^{+\infty,}\left[|k(y)||u|^{2} d y \mid .\right.
\end{aligned}
$$

Here, according to the Cauchy condition with $\varepsilon>0$, it is easy to verify that

$$
\frac{1}{2 \varepsilon}\left\|l_{t} u\right\|_{2}^{2} \geq \frac{1}{2} \int_{-\infty}^{+\infty}\left(\left|u^{(m)}\right|^{2}+c(y)|u|^{2}\right) d y-|t| \int_{-\infty}^{+\infty}|k(y)||u|^{2} d y .
$$

Using the Cauchy inequality and condition i), from inequality (5) we obtain

$$
\left\|l_{t} u\right\|_{2}^{2} \geq|t|^{2 \alpha} \delta_{0}^{2}\|u\|_{2}^{2}
$$

Combining (7) and (8), we find

$$
c\left\|l_{t} u\right\|_{2}^{2} \geq \frac{1}{2} \int_{-\infty}^{+\infty}\left(\left|u^{(m)}\right|^{2}+c(y)|u|^{2}\right) d y .
$$

From inequalities (6) and (9), we have

$$
c\left(\varepsilon, \delta_{0}\right)\left\|l_{t} u\right\|_{2}^{2} \geq \int_{-\infty}^{+\infty}\left[\left|u^{(m)}\right|^{2}+\left(c(y)+|t|^{\alpha}|a(y)|\right)|u|^{2}\right] d y,
$$

where $c\left(\varepsilon, \delta_{0}\right)>0$. 
Lemma 3. Let the condition i) is fulfilled. Then the estimate

$$
\left\|l_{t}^{-1}\right\|_{2}^{2} \leq \frac{c}{t^{2 \alpha}}
$$

holds, where $0<d<t, c>0$ are independent of $t, \alpha \in\left[\frac{1}{2}, 1\right)$.

The proof of Lemma 3 follows from Lemma 1.2.2. of paper [9].

Lemma 4. Let the condition i) is fulfilled. Then the operator $l_{t}^{-1}$ is completely continuous iff the equality (3) holds.

Proof. We will use the method proposed in the paper of M.B. Muratbekov [10] for mixed type operators.

Necessity. Suppose that the condition of Lemma 4 is not satisfied. Then there exists a sequence of intervals $Q_{d}\left(y_{j}\right) \subset R$ such that

$$
\sup \int_{Q_{d}\left(y_{i}\right)} c(t) d t<c,
$$

where $d>0$, i.e. when the interval $Q_{d}\left(y_{j}\right)$, goes to infinity with keeping length.

Let $\omega(y) \in C_{0}^{\infty}(Q(0))$. consider set of functions such that

$$
u_{j}(y)=\omega\left(y-y_{i}\right)
$$

For these functions, it is easy to establish the following inequality

$$
\left\|(-1)^{m} u_{j}^{(2 m)}(y)+\left(t k(y)+i t^{\alpha} a(y)+c(y)\right) u_{j}\right\|_{2} \leq c<\infty,
$$

holds as $o<t<N$, where $N$ is a finite number, $c$ is independent of $j$.

It is not difficult to verify it follows from Lemma 3 that

$$
\left\|l_{t}^{-1}\right\| \rightarrow 0
$$

as $t \rightarrow \infty$.

The last property was taken into account in the proof of inequality (10).

It follows from inequality (10) that

$$
F_{j}(y) \in L_{2}(R), \operatorname{supp} F_{j}(y) \subset Q_{d}\left(y_{i}\right),
$$

where $F_{j}=(-1)^{m} u_{j}^{(2 m)}+\left(t k(y)+i t^{\alpha} a(y)+c(y)\right) u$.

Now it is easy to show that the sequence $F_{j}(y)$ converges weakly to zero. Indeed

$$
\begin{gathered}
\left|<F_{j}(y), v>\right|=\left|\int_{-\infty}^{+\infty} F_{j}(y) v(y) d y\right|=\left|\int_{Q_{d}\left(y_{j}\right)} F_{j}(y) v(y) d y\right| \leq \\
\left.\left.\left.\leq\left(\int_{Q_{d}\left(y_{j}\right)} F_{j}^{2}(y)\right) d y\right)^{\frac{1}{2}} \cdot\left(\int_{Q_{d}\left(y_{j}\right)} v^{2}(y)\right) d y\right)^{\frac{1}{2}} \leq c\left(\int_{Q_{d}\left(y_{j}\right)} v^{2}(y)\right) d y\right)^{\frac{1}{2}}
\end{gathered}
$$

for any $v \in L_{2}(R)$. Obviously $\int_{Q_{d}\left(y_{j}\right)} v^{2}(y) d y \rightarrow 0$ as $j \rightarrow \infty$, since $v \in L_{2}(R)$. Hence and (11) it follows that the sequence $\left\{F_{j}(y)\right\} \rightarrow 0$ converges weakly at $j \rightarrow \infty$.

It is easy to verify that

$$
\left\|u_{j}\right\|_{2}=c>0 .
$$


Since, if the operator $l_{t}^{-1}$ is compact, then the sequence $\left\{u_{j}\right\}$ should converge to zero by norm $L_{2}(R)$. And this is impossible due to (12). The necessity is proved.

Sufficiency. Repeating the calculations and arguments used in the first part, we have

$$
R\left(l_{t}^{-1}\right) \subset L_{2}^{m}(R, c(y)),
$$

where $L_{2}^{m}(R, c(y))$ is a replenishment $C_{0}^{\infty}(R)$ by norm

$$
\|u\|_{L_{2}^{m}(R, C(y))}=\left(\int_{-\infty}^{\infty}\left(\left|u^{(m)}\right|^{2}+c(y)|u|^{2}\right) d y\right)^{\frac{1}{2}} .
$$

By the results of $[9,10]$, any bounded set in $L_{2}^{m}(R, c(y))$ is a compact in $L_{2}(R)$ if and only if the condition of $[9,10]$ are satisfied, i.e.

$$
C^{*}(y) \rightarrow \infty
$$

as $|y| \rightarrow \infty$, where $C^{*}(y)=\inf \left\{d^{-1}: d^{1-2 m}\right\} \geq \int_{y-\frac{d}{2}}^{y+\frac{d}{2}} c(t) d t$.

It follows that it is sufficient to prove the equivalence of conditions (13) and (3).

Suppose that (13) is not satisfied. Then there exists a sequence of points $y_{n}, n=0,1,2, \ldots$ and constants $c$ such that $c^{*}\left(y_{n}\right) \leq c$.

By virtue of equality

$$
d_{n}^{1-2 m}=\int_{y-\frac{d_{n}}{2}}^{y+\frac{d_{n}}{2}} c(t) d t
$$

it follows from the definition of $c^{*}(y)$, we obtain that there exist intervals $\Delta_{n}$, which go to infinity, keeping the length and

$$
\int_{\Delta_{n}} c(t) d t<c_{1}<\infty
$$

The last inequality shows that condition (3) is not satisfied.

Conversely, let condition (3) not be satisfied. Then there exist some disjoint intervals $\triangle_{n}$ which go to infinity with keeping length.

From the definition $c^{*}(y)$ we obtain $c^{*}\left(y_{n}\right) \leq c$, where $y_{n}$ is a centre of $\triangle_{n}$. This means that (13) is not satisfied, therefore (3) and (13) are equivalent. The sufficiency of Lemma 4 is proved.

Lemma 5. Let the condition i) is fulfilled and $d<t<\infty, d>0$. Then the operator $l_{t}^{-1}$ is completely continuous iff for any $\omega>0$ :

or

$$
\lim _{|y| \rightarrow \infty} \int_{y}^{y+\omega} c(t) d t=\infty
$$

$$
\lim _{|y| \rightarrow \infty} \int_{y}^{y+\omega} a(t) d t=\infty
$$

Proof. Note that the coefficient of $i\left(i^{2}=-1\right)$ under any $t$ does not vanish, since $t$ varies on the interval $(d, \infty)$.

This means that when studying the spectral properties of the operator $l_{t}^{-1}$ we must take into account the behavior of both coefficients $a(y)$ and $c(y)$.

We consider first the case (14). In this case, repeating the arguments and calculations used in the proof of Lemma 4, we obtain the proof of Lemma 5. 
Now we will consider the case (15).

Necessity. To prove this, suppose the contrary; let the conditions of the lemma not be satisfied. Then there exists a sequence of intervals $Q_{d}\left(y_{i}\right) \subset R$ such that

$$
\sup \int_{Q_{d}\left(y_{i}\right)}|a(y)| d t<c,
$$

where $d>0$. The interval $Q_{d}\left(y_{i}\right)$ goes to the infinity keeping length.

Let $\omega(x) \in C_{0}^{\infty}(Q(0))$. Consider a set of functions such that $u_{j}(y)=\omega\left(y-y_{j}\right)$. Then it is easy to estimate

$$
\left\|(-1)^{m} u_{j}^{(2 m)}+\left(t k(y)+i t^{\alpha} a(y)+c(y)\right) u_{j}\right\|_{2}^{2} \leq c<\infty,
$$

where $c$ is independent of $j$.

Let

$$
F_{j}=(-1)^{m} u_{j}^{(2 m)}+\left(t k(y)+i t^{\alpha}(a(y))+c(y)\right) u, \operatorname{supp}_{j}(y) \subset Q_{d}\left(y_{i}\right) .
$$

Hence $F_{j}(y)$ is converge weakly to zero.

The proof of necessity completes same as in Lemma 4.

Sufficiency. It follows from the results of Lemma 2 that

$$
R\left(l_{t}^{-1}\right) \subseteq W_{2, a, c}^{m}(R)
$$

where $W_{2, a, c}^{m}(R)$ is the function space with norm

$$
\left\|u: W_{2, a, c}^{m}(R)\right\|=\left(\int_{-\infty}^{\infty}\left[\left|u^{(m)}\right|^{2}+(|a(y)|+c(y))|u|^{2}\right] d y\right)^{\frac{1}{2}} .
$$

It is easy to verify that

$$
W_{2, a, c}^{m}(R) \subset W_{2, a}^{m}(R)
$$

Indeed, let $u(x) \in W_{2, a, c}^{m}(R)$. Then the estimate

$$
\int_{-\infty}^{+\infty}\left[\left|u^{(m)}\right|^{2}+|a(y)||u|^{2}\right] d y \leq \int_{-\infty}^{+\infty}\left[\left|u^{(m)}\right|^{2}+(|a(y)|+c(y))|u|^{2}\right] d y
$$

holds. The last estimate proves inclusion (17). From here and (16) we have

$$
R\left(l_{t}^{-1}\right) \subseteq W_{2, a}^{m}(R) .
$$

Further, from (18), using arguments similar to those of Lemma 4, we obtain a proof of sufficiency. Proof of continuity and discreteness theorems.

Proof of Theorem 3. Denote by $\left\{e_{n}\right\}$ complete orthonormal system of eigenvectors of the operator $A$. Then the equality

$$
\begin{gathered}
u(y)=\sum_{n=1}^{\infty} u_{n}(y) e_{n}, \\
\|u(y)\|_{H_{1}}^{2}=\sum_{n=1}^{\infty}\left\|u_{n}(y)\right\|_{2}^{2}
\end{gathered}
$$

holds for all $u(y) \in H$. 
Immediately following equality is easily verified

$$
\begin{gathered}
A u=\sum_{n=1}^{\infty} \lambda_{n} u_{n}(y) e_{n} ; \\
A^{\alpha} u=\sum_{n=1}^{\infty} \lambda_{n}^{\alpha} u_{n}(y) e_{n} .
\end{gathered}
$$

This shows that the separation of the variables of the spectral problem

$$
L u=\lambda u
$$

reduces to the following spectral problems

$$
\begin{gathered}
-u_{n}^{(2 m)}(y)+\left(k(y) \lambda_{n}+i a(y) \lambda_{n}^{\alpha}+c(y)\right) u_{n}=\lambda u_{n}(y), \\
n=1,2,3, \ldots
\end{gathered}
$$

If $\lambda$ is a spectrum point of $L$, then $\lambda$ is the spectrum point of one of the operators (19). And vice versa, if $\lambda$ is a spectrum point of one of the operators (19), then $\lambda$ is the spectrum point of $L$.

Now, if we use the assumption of Theorem 1, that $\lambda=0$ is an eigenvalue of finite multiplicity, then Theorem 3 follows easily from Lemma 1.

Proof of Theorem 4. Similarly reasoning and using Lemma 2 we obtain the proof of Theorem 4.

Proof of Theorem 5. In Theorem 5, we assumed that the operator $A$ is the positive definite selfadjoint with a completely continuous inverse, and this is due to the fact that the smallest eigenvalue of this operator is nonzero. Now the theorem being proved follows from Lemma 4.

\section{On the properties of a resolvent of a single unbounded high-order differential operator with an operator coefficient}

Let $H$ is the separable Hilbert space. Denote by $C_{0}^{\infty}(R, H)$ is the set of infinitely smooth compactly supported functions defined on $R(-\infty,+\infty)$ with value in $H$.

Consider the differential operator

$$
L u \equiv(-1)^{m} u^{(2 m)}(y)+k(y) A u+i a(y) A^{\alpha} u+c(y) u,
$$

where $m=1,2, \ldots, u(y) \in C_{0}^{\infty}(R, H), A$ is the positive definite self-adjoint operator in the Hilbert space $H$ with a completely continuous resolvent, $\alpha \in\left[\frac{1}{2}, 1\right), k(y)$ is the piecewise continuous and bounded function in $R, k(0)=0$ and $y k(y)>0$ at $y \neq 0$.

Let the conditions

1) $|a(y)| \geq \delta_{0}>0, c(y) \geq \delta>0$ is continuous functions in $R$,

2) $\sup _{|x-t| \leq 1} \frac{a(t)}{a(x)} \leq c<\infty, \sup _{|x-t| \leq 1} \frac{c(t)}{c(x)} \leq c_{0}<\infty$;

3) $0<\delta_{1} \leq \frac{a^{2}(y)}{c(y)}$ at $y \in R$ hold.

The following theorems hold.

Theorem 6. Let conditions 1) -3) are fulfilled. Then the resolvent of the operator $L$ belong to $\sigma_{p}$ if $p>1$ and

$$
\sum_{j=1}^{\infty} \int_{-\infty}^{\infty} Q^{\frac{m(-p+1)}{2}}(j, y) d y<\infty
$$

where $\sigma_{p}$ is the set of all completely continuous operators such that $\|A\|_{\sigma_{p}}^{p}=\sum_{n=1}^{\infty} S_{n}^{p}(A)<\infty, S_{n}(A)$ is an eigenvalues of $\sqrt{A^{*} A}, Q(t, y)=\left|a(y) i t^{\alpha}+c(y)\right|^{2}$. 
Theorem \%. Let conditions 1) -3) are fulfilled and

$$
\sum_{n=1}^{\infty} n^{l} \lambda_{n}^{-1}<\infty,
$$

for all $0 \leq l<1+s, s>0$, where $\lambda_{n}$ is an eigenvalues of $A$. Then the resolvent of the operator $L$ is a Hilbert-Schmidt operator if $a^{-m}(y) \in L_{1}(R)$.

To prove the above theorems, we use the following auxiliary statements and estimates.

Consider the operator defined by the equality

$$
l_{t}=(-1)^{m} u^{(2 m)}+\left(t k(y)+i t^{\alpha} a(y)+c(y)\right) u
$$

in $L_{2}(R), d<t<\infty$.

It is known from the results of the first part that, under conditions 1)-3), there exists a resolvent $l_{t}$ and the estimate

$$
\left\|u^{(m)}\right\|_{2}^{2}+\left\|i t^{\alpha} a(y) u\right\|_{2}^{2}+\|c(y) u\|_{2}^{2} \leq c\left(\left\|l_{t} u\right\|_{2}^{2}+\|u\|_{2}^{2}\right),
$$

holds for all $u \in D\left(l_{t}\right)$, where $c>0$ is independent of $u$ and $t$.

Let $A$ be a completely continuous operator. It is known that the eigenvalues of the operator $\left(A^{*} A\right)^{\frac{1}{2}}$ are called $s$-numbers of $A$. Nonzero $s$-numbers will be numbered in decreasing order, taking into account their multiplicity, so

$$
s_{j}(A)=\lambda_{j}\left(\left(A^{*} A\right)^{\frac{1}{2}}\right), j=1,2, \ldots
$$

We introduce the following function $N(\lambda)=\sum_{s_{j}>\lambda} 1$ is the number $s_{j}$ greater than $\lambda>0$. Let

$$
M=\left\{u \in L_{2}(R):\left\|l_{t} u\right\|_{2}^{2}+\|u\|_{2}^{2} \leq 1\right\} .
$$

Denote by $d_{k}$ is the Kolmogorov $k$-width of the set $M$ in $L_{2}(R)$.

By definition

$$
d_{k}=\inf _{\left\{\varphi_{k}\right\}} \sup _{u \in M} \inf _{v \in \varphi_{k}}\|u-v\|_{2},
$$

where "infimum"takes over all subspaces $\varphi_{k}$ dimensionality $\leq k$.

Lemma 6. Suppose that the conditions of Theorem 4 are satisfied. Then the estimate

$$
d_{k} \leq c^{2} \tilde{d}_{k},
$$

holds, where $\tilde{d}_{k}$ is the Kolmogorov $k$-width of the set

$$
\tilde{M}=\left\{u \in L_{2}(R):\left\|u^{(2 m)}\right\|_{2}^{2}+\|c(y) u\|_{2}^{2}+\left\|t^{\alpha} a(y) u\right\|_{2}^{2} \leq 1\right\},
$$

where $c>0$ is any constant.

Proof. It follows from the hypothesis of the lemma that the estimate (20) holds for all $u \in D\left(l_{t}\right)$. Hence

$$
\left\|u^{(m)}\right\|_{2}^{2}+\left\|t^{\alpha} a(y) u\right\|_{2}^{2}+\|c(y) u\|_{2}^{2} \leq c^{2}\left(\left\|l_{t} u\right\|_{2}^{2}+\|u\|_{2}^{2}\right) \leq c^{2},
$$

for all $u \in M$, where $c>0$ is a constant independent of $t$ and $u$.

Therefore $M \subseteq \tilde{M}_{c^{2}}$.

Now, using the property of the widths, we have

$$
d_{k} \leq c^{2} \tilde{d}_{k}
$$

Lemma 6 is proved. 
Lemma \%. Let the conditions of Theorem 4 is satisfied. Then the estimate

$$
N(\lambda) \leq \tilde{N}\left(c^{-2} \lambda\right)
$$

holds, where $N(\lambda)=\sum_{d_{k}>\lambda} 1$ is the number of width $d_{k}$ greater than $\lambda>0, \tilde{N}(\lambda)=\sum_{d_{k}>\lambda} 1$ is the number of width $\tilde{d}_{k}$ greater than $\lambda>0$.

Proof. By virtue of Lemma 6 we have

$$
N(\lambda)=\sum_{d_{k}>\lambda} 1 \leq \sum_{c^{2} \tilde{d}_{k}>\lambda} 1=\sum_{\tilde{d}_{k}>c^{-2}} \lambda 1=\tilde{N}\left(c^{-2} \lambda\right) .
$$

Lemma 7 is proved.

Denote by $\tilde{N}(\lambda)=\sum_{\lambda_{j}>\lambda} 1$ number of singular numbers $s_{j}(j=1,2, \ldots)$ of $l_{t}^{-1}$ greater than $\lambda>0$.

Lemma 8. Let the conditions of Lemma 7 be satisfied, then the estimate

$$
\tilde{N}(\lambda) \leq c \lambda^{-\frac{1}{m}} \operatorname{mes}\left(y \in R: Q^{\frac{m}{2}}(t, y) \leq c \lambda^{-1}\right),
$$

holds, where $c$ is a constant independent of $Q(t, y)$.

Proof. It is known

$$
s_{j+1}\left(l_{t}^{-1}\right)=d_{j}, j=1,2, \ldots
$$

where $d_{j}, j$ is the width of $M$.

Denote by $L_{2, Q(t, y)}^{m}$ space obtained by replenishment $C_{0}(R)$ relative to the norm

$$
\left|u, L_{2, Q(t, y)}^{m}\right|=\left(\int_{-\infty}^{+\infty}\left|u^{(m)}\right|^{2}+Q(t, y)|u|^{2} d y\right)^{\frac{1}{2}}
$$

It is clear that $\tilde{N} \subset L_{2, Q(t, y)}^{m}$.

Now the proof of the lemma follows from Lemmas 6 and 7 and the results of [10].

Proof of the main theorems.

Denote by $s_{j i}$ singular numbers of $l_{j}, j=1,2, \ldots$ It is easy to verify the inequality

$$
\sum_{j} \sum_{i} s_{j i} \leq c \sum_{j} \sum_{i} d_{j i}
$$

holds. Let

$$
F(\lambda)=N\left(\lambda^{-1}\right),
$$

where $N(\cdot)$ is the function of the distribution widths $d_{j i}, i=0,1,2, \ldots$ greater than $\lambda>0$. Note that $F(\lambda)=0$ if $\lambda \leq \delta_{j 0}=\frac{1}{d_{j 0}}$.

Since $F\left(\lambda_{j}\right)=j$ at $\lambda_{j}=d_{j i}^{-1}$, then

$$
\sum_{j} \sum_{i=1}^{\infty} d_{i j}^{p}=\sum_{j} \lim _{N \rightarrow \infty} \sum_{i=0}^{N} d_{j i}^{p}=\sum_{j} \lim _{N \rightarrow \infty} \sum_{i=0}^{N} \lambda_{j i}^{-p}=\sum_{j} \lim _{N \rightarrow \infty} \int_{0}^{\lambda_{n}} \lambda_{j}^{-p} d F\left(\lambda_{j}\right)=\sum_{j} \int_{0}^{\infty} \lambda_{j}^{-p} d F\left(\lambda_{j}\right) .
$$

We transform the internal integral like follows.

Let $\alpha_{i}=d_{j i+1}^{-1}$, where $\left\{d_{j i+1}^{-1}\right\}_{i=0}^{\infty}$. Then integrating by parts, we have

$$
\int_{0}^{\alpha_{i}} \lambda_{j}^{-p} d F\left(\lambda_{j}\right)=\int_{\delta_{j 0}}^{\alpha_{i}} \lambda_{j}^{-p} d F\left(\lambda_{j}\right)=\lambda_{j}^{-p} F\left(\lambda_{j}\right)-\int_{0}^{\alpha_{i}} \lambda_{j}^{-p-1} F\left(\lambda_{j}\right) d \lambda_{j}=
$$




$$
=\lambda_{j}^{-p} F\left(\alpha_{i}\right)-\delta_{j o}^{-p} F\left(\delta_{i} 0\right)-\int_{0}^{\alpha_{j i}} \lambda_{j}^{-p-1} F\left(\lambda_{j}\right) d \lambda_{j},
$$

where $\delta_{j 0}=\frac{1}{d_{j 0}}$. So $F\left(\delta_{j 0}\right)=0$.

Due to the last equality, this equality takes the following form

$$
\int_{0}^{\alpha_{j i}} \lambda_{j}^{-p} d F\left(\lambda_{i}\right)=\alpha_{j i}^{-p} F\left(\alpha_{j i}\right)-\int_{0}^{\alpha_{i}} \lambda_{j}^{-p-1} F\left(\lambda_{j}\right) d \lambda_{j} .
$$

Using the condition of Theorem 6 we obtain

$$
\begin{aligned}
& \int_{-\infty}^{+\infty} Q^{\frac{m(-p+1)}{2}}(j, y) d y \geq \int_{m e s\left(y \in R: Q^{-\frac{m}{2}}(j, y) \geq c \lambda\right)} Q^{\frac{m(-p+1)}{2}}(j, y) d y \geq \\
\geq & \int_{m e s\left(y \in R: Q^{-\frac{m}{2}}(j, y) \geq c \lambda\right)} Q^{\frac{-m(-p+1)}{2}}(j, y) d y= \\
= & \int_{m e s\left(y \in R: Q^{-\frac{m}{2}}(j, y) \geq c \lambda\right)} Q^{-\frac{m}{2} \cdot(p-1)} d y \geq \lambda^{p-1} \operatorname{mes}\left(y \in R: Q^{-\frac{m}{2}}(j, y) \geq c \lambda\right) .
\end{aligned}
$$

Hence

$$
\operatorname{mes}\left(y \in R: Q^{\frac{m}{2}}(j, y) \leq c \lambda^{-1}\right) \leq \frac{A}{\lambda^{p-1}}=A \lambda^{-(p-1)}
$$

where $A=\int_{-\infty}^{+\infty} Q^{\frac{m(-p+1)}{2}}(j, y) d y$.

From the last inequality and Lemma 8 , we have

$$
N(\lambda) \leq c \frac{A}{\lambda^{(p-1)+\frac{1}{m}}}=c A \lambda^{-p+1-\frac{1}{m}} .
$$

Hence we obtain

$$
d_{j k}^{p} \leq c \frac{A^{\frac{p}{\left(p-\left(1-\frac{1}{m}\right)\right)}}}{(k+1)^{\frac{p}{\left[p-\left(1-\frac{1}{m}\right)\right]}}} .
$$

This inequality shows that outside the integral term of equality (21) is equal to zero as $k \rightarrow \infty$.

Now it remains to calculate the integral $\int_{0}^{\infty} \lambda_{j}^{-p-1} F\left(\lambda_{j}\right) d \lambda_{j}$. Directly calculating, taking into account Lemma 8, we have

$$
\begin{gathered}
\int_{0}^{\infty} \lambda_{j}^{-p-1} F\left(\lambda_{j}\right) d \lambda_{j} \leq c \int_{0}^{\infty} \lambda_{j}^{-p-1} \lambda_{j} \operatorname{mes}\left(y \in R: Q^{\frac{m}{2}}(t, y) \leq c \lambda\right) d \lambda_{j}= \\
=c_{1} \int_{0}^{\infty} \lambda_{j}^{-p} m e s\left(y \in R: Q^{\frac{m}{2}}(t, y) \leq c \lambda_{j}\right) d \lambda_{j}=c_{1} \int_{0}^{\infty} m e s\left(y \in R: Q^{\frac{m}{2}}(t, y) \leq c \lambda_{j}\right) d \lambda_{j}^{-p+1}= \\
=c_{1} \lambda_{j}^{-p+1} m e s\left(y \in R: Q^{\frac{m}{2}}(t, y) \leq c \lambda_{j}\right)-c_{1} \int_{0}^{\infty} \lambda_{j}^{-p+1} d m e s\left(y \in R: Q^{\frac{m}{2}}(t, y) \leq c \lambda_{j}\right) .
\end{gathered}
$$

All outside integral terms disappear. 
It remains to verify that

$$
\int_{0}^{\infty} \lambda_{j}^{-p+1} d m e s\left(y \in R: Q^{\frac{m}{2}}(t, y) \leq c \lambda_{j}\right)=\int_{0}^{\infty} Q^{\frac{m}{2} \cdot(-p+1)}(t, y) d y .
$$

Indeed, this follows from the fact that for any sequence of points

$$
\delta_{j 0}^{2} \leq \xi_{0} \leq \xi_{1} \leq \xi_{2} \leq \ldots \leq \xi_{k} \leq \ldots
$$

correspond to Darboux sums

$$
\begin{aligned}
& \bar{S}=\sum_{k=1}^{\infty} M_{k} m e s \Omega_{k} ; \\
& \underline{S}=\sum_{k=1}^{\infty} m_{k} m e s \Omega_{k},
\end{aligned}
$$

where $\Omega_{k}=\left\{x \in R: \xi_{k-1} \leq Q^{\frac{m}{2}}(t, y) \leq \xi_{k}\right\}$,

$$
M_{k}=\sup _{x \in \Omega_{k}} Q^{\frac{m}{2} \cdot(-p+1)}(t, y), m_{k}=\inf _{x \in \Omega_{k}} Q^{\frac{m}{2} \cdot(-p+1)}(t, y) .
$$

The inequality

$$
\sum_{k=1}^{\infty} \xi_{k}^{-p+1} m e s \Omega_{k} \leq \underline{S} \leq \bar{S} \leq \sum_{k=1}^{\infty} \xi_{k-1}^{-p+1} m e s \Omega_{k}
$$

holds. If the right integral exists in (22), then, by virtue of (23), there exists the left integral and they are equal.

Theorem 6 is proved.

Proof of Theorem 7. We have

$$
\begin{gathered}
Q^{-\frac{m}{2}}(n, y)=\frac{1}{\left|i \lambda_{n}^{\alpha} a(y)+c(y)\right|^{m}} \leq \frac{1}{\lambda_{n}^{m \alpha}|a(y)|^{m}}, \\
n=1,2,3, \ldots
\end{gathered}
$$

This and Lemma 6 it follows that

$$
\sum_{n=1}^{\infty} \int_{-\infty}^{+\infty} Q^{-\frac{m}{2}}(n, y) d y \leq \sum_{n=1}^{\infty} \frac{1}{\lambda_{n}^{m \alpha}} \int_{-\infty}^{+\infty} \frac{1}{|a(y)|^{m}} d y=\int_{-\infty}^{+\infty} \frac{1}{|a(y)|^{m}} d y \sum_{n=1}^{\infty} \frac{1}{\lambda_{n}^{m \alpha}}
$$

Now, using condition 2), from the last inequality we obtain the proof of Theorem 5 .

This work was done on grant financing of the Ministry of Education and Science of the Republic of Kazakhstan on project AP05131080.

\section{References}

1 Левитан Б.М. Исследование функции Грина уравнения Штурма-Лиувилля с операторным коэффициентом / Б.М. Левитан // Мат. сб. - 1968. - Т. 76(118). - № 2. - С. 239-270.

2 Отелбаев М. Об условиях самосопряженности оператора Штурма-Лиувилля с операторным потенциалом / М. Отелбаев // Украин. мат. журн. - 1983. - Т. 28. - № 6. - С. 763-771. 
3 Левитан Б.М. Достаточные условия дискретности спектра уравнения Штурма-Лиувилля с операторным потенциалом / Б.М. Левитан, Г.А. Суворченкова // Функциональный анализ и его приложения. - 1968. - Т. 2. - № 2. - С. 56-62.

4 Горбачук В.И. О некоторых классах граничных задач для уравнения Штурма-Лиувилля с операторным потенциалом / В.И. Горбачук, М.Л. Горбачук // Украин. мат. журн. - 1972. - T. 23. - № 3. - C. 291-305.

5 Гехтман И.М. О спектре операторного уравнения Штурма-Лиувилля / И.М. Гехтман // Функциональный анализ и его приложения. - 1972. - Т. 6. - № 2. - С. 81-82.

6 Михалец В.А. Распределение собственных значений операторного уравнения ШтурмаЛиувилля / В.А. Михалец // Изв. АН СССР. - 1977. - Т. 41. - № 3. - С. 607-619.

7 Мишневский П.А Функция Грина и асимптотическое поведение собственных значений операторной задачи Штурма-Лиувилля / П.А Мишневский // ДАН СССР. - 1987. - Т. 203. - № 4. - C. $726-765$.

8 Муратбеков М.Б. Коэрцитивная разрешимость дифференциального уравнения нечетного порядка и ее приложения / М.Б. Муратбеков, М.М. Муратбеков, К.Н. Оспанов // Док. АН РФ. - 2010. - T. 435. - № 3. - C. 1-3.

9 Муратбеков М.Б. Коэрцитивные оценки для одного дифференциального оператора высокого порядка / М.Б. Муратбеков // Дифференциальные уравнения. - 1981. - Т. 17. - № 5. - C. 893-901.

10 Muratbekov M.B. Two sides of the distribution function of s-values of class of mixed type differential operators / M.B. Muratbekov // Complex Variables and Elliptic Equations. - 2007. - Vol. 57. - № 12. - P. 1121-1144.

М.Б. Мұратбеков, С.Ж. Игисинов, Б.М. Мүсілімов, Р.Р. Мақұлбекова

\title{
Операторлы коэффициентті жоғары ретті дифференциалдық операторлардың бір класының спектральді қасиеттері туралы
}

\begin{abstract}
Мақалада жоғары ретті дифференциалдық операторлардың бір класы зерттелген. Мұндай операторлардың негізгі ерекшелігі олардың жартылай шенелмеген болуында. Операторлы коэффициенттердің айнымалыларға тәуелді болуы зерттеуде қосымша қиындықтар туғызады. Зерттеу барысында ең алдымен шешімнің бар болу шарттары және бөліктенуі анықталған. Сонымен қатар айнымалы операторлы коэффициентті жартылай шенелмеген дифференциалдық теңдеулер үшін шешімнің тегістігі және шекаралық есептердің спектріне қатысты мәселелер зерттелген.
\end{abstract}

Kiлm сөздер: дифференциалдық оператор, жартылай шенелмегендік, операторлы коэффициент, спектр.

М.Б. Муратбеков, С.Ж. Игисинов, Б.М. Мусилимов, Р.Р. Макулбекова

\section{О спектральных свойствах одного класса дифференциальных операторов высокого порядка с операторными коэффициентами}

\footnotetext{
В статье исследован один класс дифференциальных операторов высокого порядка. Главной особенностью данных операторов является их неполуограниченность. Зависимость операторных коэффициентов от переменных создает дополнительные трудности в исследовании. В ходе исследования сначала найдены условия существования решения и разделимости. Также изучены вопросы гладкости решений и о спектре краевых задач для неполуограниченных дифференциальных уравнений с переменными операторными коэффициентами.
}

Ключевые слова: дифференциальный оператор, неполуограниченность, операторный коэффициент, спектр. 


\section{References}

1 Levitan, B.M. (1968). Issledovanie funktsii Hrina uravneniia Shturma-Liuvillia s operatornym koeffitsientom [Investigation of the Greens function of the Sturm-Liouville equation with an operator coefficient]. Matematicheskii sbornik - Mathematical collection, 76(118), 2, 239-270 [in Russian].

2 Otelbaev, M. (1983). Ob usloviiakh samosopriazhennosti operatora Shturma-Liuvillia s operatornym potentsialom [On self-adjointness conditions for the Sturm-Liouville operator with operator potential]. Ukrainskii matematicheskii zhurnal - Ukrainian Mathematical Journal, 28, 6, 763-771 [in Russian].

3 Levitan, B.M. \& Suvorchenkova, G.A. (1968). Dostatochnye usloviia diskretnosti spektra uravneniia Shturma-Liuvillia s operatornym potentsialom [Sufficient conditions for the discreteness of the spectrum of the Sturm-Liouville equation with operator potential]. Funktsionalnyi analiz i eho prilozheniia - Functional analysis and its applications, 2, 2, 56-62 [in Russian].

4 Gorbachuk, V.I. \& Gorbachuk, M.L. (1972). O nekotorykh klassakh hranichnykh zadach dlia uravneniia Shturma-Liuvillia s operatornym potentsialom [On some classes of boundary value problems for the Sturm-Liouville equation with operator potential]. Ukrainskii matematicheskii zhurnal - Ukrainian Mathematical Journal, 23, 3, 291-305 [in Russian].

5 Gekhtman, I.M. (1972). O spektre operatornoho uravneniia Shturma-Liuvillia [On the spectrum of the operator Sturm-Liouville equation]. Funktsionalnyi analiz $i$ eho prilozheniia - Functional analysis and its applications, 6, 2, 81-82 [in Russian].

6 Mihalec, V.A. (1977). Raspredelenie sobstvennykh znachenii operatornoho uravneniia ShturmaLiuvillia [Distribution of eigenvalues of the operator Sturm-Liouville equation]. Izvestiia AN SSSR - Proceedings of the USSR Academy of Sciences, 41, 3, 607-619 [in Russian].

7 Mishnevskij, P.A. (1987). Raspredelenie sobstvennykh znachenii operatornoho uravneniia Shturma-Liuvillia [Green function and asymptotic behavior of the eigenvalues of the operator Sturm-Liouville problem]. DAN SSSR - DAN USSR, 203, 4, 726-765 [in Russian].

8 Muratbekov, M.B. \& Muratbekov, M.M. \& Ospanov, K.N. (2010). Koertsitivnaia razreshimost differentsialnoho uravneniia nechetnoho poriadka i ee prilozheniia [Coercive solvability of an oddorder differential equation and its applications]. Doklady Akademii nauk RF-Reports of the Academy of Sciences of the Russian Federation, 435, 3, 1-3 [in Russian].

9 Muratbekov, M.B. (1981). Koertsitivnye otsenki dlia odnoho differentsialnoho operatora vysokoho poriadka [Coercive estimates for one high-order differential operator]. Differentsialnye uravneniia - Differential equations, 17, 5, 893-901 [in Russian].

10 Muratbekov, M.B. (2007). Two sides of the distribution function of s-values of class of mixed type differential operators. Complex Variables and Elliptic Equations, 57, 12, 1121-1144. 